\title{
Provincialising the Italian Effect
}

\section{BRETT NEILSON}

UNIVERSITY OF WESTERN SYDNEY

\section{- HAS THERE BEEN AN ITALIAN EFFECT?}

Following the title of a book edited by Michael Hardt and Paolo Virno, the conference from which this special section of Cultural Studies Review springs aimed to assess the global influence of 'radical Italian thought' over the past decade. ${ }^{1}$ It is no secret that, following the international reception of Michael Hardt and Antonio Negri's Empire, there has been heightened interest in the multiple currents of radical political thought that have emerged from Italy. ${ }^{2}$ Indeed, these strains of thought have provided some of the most productive avenues for investigating global complexities such as the changing patterns of sovereignty, the connections between biology and politics, the increasing significance of networked media, and the growing precariousness of labour. In Italy, importantly, this radical thought was forged in a concrete context of struggle, beginning with the working class and feminist struggles of the 1960s and feeding through to the current expressions of social movements. But what are the stakes in transporting such thought to other parts of the world? What happens when radical Italian thought is uprooted from its initial context of formation and put to work in other contexts? Must this involve an objectification of the subjective processes of thought, their reification into theory? Or is the network of brains and bodies by now so globally extensive that the necessary translations can be accomplished notwithstanding the local specificity of experiences and cultures? 
Laboratory Italy: that is the familiar moniker used to describe the cultural and social circumstances that set in train the remarkable wave of political experimentation that swept Italy from the late 1950s. Accompanied by rapid processes of industrialisation and class recomposition, it is no overestimation to claim that the heterogeneous amalgam of thought and practice that is often dubbed operaismo or composizionalismo (however inadequate these labels may be) gave rise to new forms of political life. Based in the materiality of movements and struggles, these modalities of political thought and practice placed an emphasis on workers' subjectivity, which allowed a break with statist-communist orthodoxies and the glimpse of an exit from capitalist civilisation.

It is impossible to do justice to the richness of this history: its internal posing of the relations between the activist-intellectual and social movements; its working through little magazines and other independent media; its entanglement with the youth and student movements; the fallouts and fractures over questions of organisation; the exodus of feminist intellectuals; the moments of repression, exile and amnesty; the triumph of capitalist restructuring in the 1980s and disappearance of the great workers' coalitions; the consequent weakening of the left hegemony over cultural life and rise of berlusconismo; the violent explosion at the Genoa G8 protests of 2001 and long season of the 'new global' movement. All this is part of a lived history in which Italy could, at one stage or another, be identified as the anello debole (weak link) in the global chain of imperial command. And while it is unquestionable that operaismo is dead as an experience, there is a sense in which it remains a live political bodyone that cannot fail to galvanise the present whenever it is remembered, if only for its insistence on a new way of being political.

But what form does this live political body take in the present global conjuncture? In Italy, across the 1990s, there was already a perceived move beyond operaismo. The emergence of socalled postoperaismo, associated with journals such as Luogo Commune, DeriveApprodi, and the French Futur Antérieure (started by Negri in Paris with the contribution of a number of Italian political refugees), involved an attempt to understand the potential conflict between new forms of society and the productive regime that had established itself upon the ruins of Fordism. Immaterial labour, cognitive capitalism and the society of control became the key concepts by which the global processes of capitalist restructuring were assessed vis-à-vis the subjective actions of workers, migrants and other collective bodies, as well as the changed technical conditions for the constitution of life. Not only was there a heady confidence regarding the decline of nation-state sovereignty but also a renewed practice of protest that took the virtual domain of the Internet as both its point of departure and political application. To what extent 
have the conditions of this thought remained intact? 'The panorama has changed', declares Franco Berardi (alias Bifo), taking stock of the violence perpetrated by the Italian state at Genoa, the post-9/11 escalation of 'global civil war', and the media torture emanating from Baghdad's Abu Ghraib prison. ${ }^{3}$ Under these conditions, there is a need to reassess the patrimony of radical Italian thought, not only to derive conceptual and political instruments to confront the current global situation but also to live in spite of it, to uncover modes of imagination, affect and relation that sneak beneath the screens of military and financial control.

This was the compito of the 'Italian Effect' conference, held in Sydney, Australia (9-11 September 2004). In an important sense, the site of this event was accidental, resulting from a series of chance encounters, intermittent friendships, and unstable networks of intellectual and political association. But, while the choice of city was not intended to reflect any particularly pronounced or unusual uptake of radical Italian thought, the ensuing discussions and debates were by no means untouched by the contingencies of geographical location. To assess the legacy and utility of the thought that has emerged from Laboratory Italy in a distant context is to ask questions about the limits and qualities of that thought, to 'provincialise' it, to identify both its possibilities for contagion with other theories and practices and its shortcomings in responding to questions and problems that are foreign to the Italian context. Such a process must always involve translation, not only in the linguistic sense but also in the wider political and cultural senses. And, as with all translation, there is something to be gained as well as lost.

Key to understanding the workings of such translation is an awareness of how the displacement (and distant reception) of thought bears upon political practice. As a global city, whose political life can be assimilated to neither ancient polis nor modern state, Sydney generates urban complexities that twist and complicate the favoured categories of Italian political analysis. Any political engagement in such a city must begin by asking what it means for people of different (and overlapping) cultural backgrounds to inhabit the same space. And this raises challenges for a tradition like operaismo that, despite its affinities to postcolonial thought, was forged in a relatively monocultural context: the rapidly industrialising Italy of the late 1950s to $1960 s^{4}$

Sydney never did experience widespread industrial transformation. Always a colonial outpost, it lived off the back of mining and agriculture, until emerging in the 1980s as a financial centre, hardwired into global markets and carrying with it all the consumer service options that accompany the financialisation of everyday life. Does it make sense to deploy the favoured categories of radical Italian thought in this context, to speak, for instance, of a 'social factory' to youth who have never been inside a factory and probably never will? Young people in cities like 
Sydney have grown up in shopping malls, learned to speak from television. Their proletariatisation consists in being socialised to debt and primed for 'cognitive labour' that aspires, however precariously, to capture and milk the global financial matrix? The insights about the socialisation of capital, the general intellect and the exploitation of networks of collaboration may remain. But the metaphors must shift, mutate, and undergo translation if they are to be made politically effective.

No doubt, it is possible to identify episodes or actions that attempt to bring Laboratory Italy to life in Sydney. One thinks of the experiments surrounding the establishment of social centres such as the Grand Midnight Star or the Balloon Factory-short-lived ventures that bear strong marks of autonomist organisation. Similarly, there have been lines of influence and dialogue at the level of intellectual production. Take, for instance, Meaghan Morris's 1978 article 'Eurocommunism versus Semiotic Delinquency', which was published by the small local press Feral Publications - the piece offers an impressive analysis of the student movement of Bologna 1977.5 But these patterns of influence and exchange (like those established by the Italian Effect conference itself) are relatively minor if placed in the overarching context of the Sydney intellectual and political scene, which remains dominated by left nationalist and rights-based agendas. Not until quite recently, with the publication of Hardt and Negri's Empire, did the influence of radical Italian thought in Australia became more pronounced. Combined with an interest in the work of Giorgio Agamben (particularly among those seeking to understand the political structure of Australia's detention camps) and the reception of critical feminist texts by Adriana Cavarero and other members of the Diotima feminist community, Empire provided a kind of bridge between the Italian political context and the English-speaking world. And, as much as we can trace earlier efforts of translation and commentary to figures like Ed Emery and Harry Cleaver, it is really with the ruckus created by Empire that the present interest in operaista and postoperaista thought, in Sydney as much as in other major English-speaking cities, finds its impetus.

-UN OPERAISMO GLOBALE?

Signal of the impact of Hardt and Negri's book is that even now, in the wake of the publication of Multitude, it continues to attract critical comment. ${ }^{6}$ A recent review entitled 'Internationalism Revisited' by the postcolonial critic Benita Parry places the problematic I wish to raise squarely on the table. Parry writes with suspicion of Hardt and Negri's transposition of 'the localized theoretical heritage of the autonomia movement onto a world arena'. 'It is salutary', she writes, 'to contrast the indiscrimination of the fuzzy world-outlook pervading Empire with the close analyses of geographical terrains, institutional structures, modes of production and class forces 
undertaken by Marxist theorists in the colonized world when devising their own experiments in revolution'.7 Parry's emphasis on 'modes of production' and 'institutional structures' betrays her unfamiliarity with the very 'theoretical heritage' she wishes to question. But, while there is much to contest in her polemic (which culminates by arguing that radical politics must be organised through the party form), the point about the transportability of radical Italian thought, I think, is apposite to any inquiry that seeks to assess the influence and utility of that thought in the present global conjuncture. Just how provincial is the theoretical heritage we associate with operaismo? And what happens when it begins to travel beyond the context of its formation, to assert itself in other contexts and struggles that are remote from (but also connected to) the peculiar circumstances of social composition in which it first took hold.

This is not a series of questions to which operaista thinkers are remote, partly because after the clampdown of 7 April 1979 (when the Italian state rounded up and imprisoned many of the intellectuals associated with the movement), so many of them were impelled to travel. Perhaps it was the circumstances surrounding this mobility (repression, defeat, emergency laws, incarceration) that compelled many of these figures to seek shelter and solidarity not only in the political-juridical sense but also in terms of intellectual affinities. In a 2002 interview with Danilo Zolo, Antonio Negri recalls how his 1983 arrival in Paris was accompanied by the realisation that operaismo was by no means a provincial phenomenon. ${ }^{8} \mathrm{He}$ refers to certain common tendencies between operaismo, French poststructuralism, and the 'subaltern studies' writings. But Negri was not alone in this search for intellectual synergies. In his interview for the 2001 DeriveApprodi volume Futuro Anteriore, Christian Marazzi remembers his surprise to discover in New York City in the late 1970s a fervent interest in operaismo. ${ }^{9}$ He talks, for instance, of the interest expressed by the musician David Byrne, an interest that he notes was primarily aesthetic-cultural in orientation. And he remarks that the emergence of an international operaismo was based not simply in the need to find allies but in the movement of thought through real experiences, grounded in artistic/cultural ambiences as well as political solidarities.

Importantly, this was also the period in which Marazzi collaborated with Sylvere Lotringer in the production of the 1980 Semiotext(e) volume entitled Autonomia: Postpolitical Politics, a publication in which he expresses the notion that there is nothing 'Italian' about operaista thought.

What can be considered the most original theoretical contribution to Italian workerism originated abroad ... There is nothing 'Italian' about the class warfare in Italy ... To erect a monument to Italy is to play the game of 
the Italian State: to misrepresent as specific ('the production of certain intellectuals') what was in fact rooted in the worker's history, rooted, above all, in its international dimension. ${ }^{10}$

These words provide a warning to anyone who wants to fantasise that there is anything 'Italian' about the so-called Italian effect. Without denying the specific contributions of thinkers like Mario Tronti and Romano Alquati, they are a call to cut the cord of philology and abandon the notion that an engagement with radical Italian thought must fall under the disciplinary sway of Italian studies or encourage modes of address restricted either to 'the international English' or 'my national language'.

With their emphasis on workers' history rather than intellectual production, Lotringer and Marazzi point beyond the reterritorialising game of the Italian state. And they problematise any attempt to reduce the wider global interest in operaismo to an intellectual trend, a form of fashion that would affirm that beloved fantasy of the Italian capitalist class-the allure of the 'made in Italy' label. No doubt, there is a moment of truth to such claims, particularly as regards the intersection between the global circulation of ideas and the functioning of academic job and book markets. But such combinations do not necessarily lessen the critical force of radical Italian thought. Furthermore, the perception that the response to such thought in the English-speaking world has been primarily a matter of fashion or aesthetics is not one restricted to conservative or left nationalist forces in its sites of reception but also one entertained within the Italian movements themselves. What is required is a rigorous examination of the peculiarity and transferability of operaista thought, not simply in terms of the problematic that Edward Said once called travelling theory but also with regard to the complex intersection between the Marxist analytic of abstract labour power and the cultural hermeneutics of place.

To speak of provincialising the Italian effect is not to declare what history has already accomplished (the provincialisation of the Italian peninsula). Nor is it to identify the context in which radical Italian thought is received as some kind of centre. Part of what I have been trying to do is to situate the circulation and reception of this thought within geographical parameters. But this is not to buy into a centre-periphery logic that carves up the globe into dependent and neo-imperial states. Nor is it to promote the fiction of Italy as a utopia of political expression, a theory-producing machine, or some kind of heaven of cultural subversion. Undeniably the expressions of the 'new global' movement in Italy have been impressive and there is something exemplary about the intertwining of political and intellectual expression in the Italian laboratory. But to build this into a fantasy of Italian exceptionalism is to fall prey to an idealising 
logic that fails to recognise that, despite the remarkable force of struggle, the defeat of the working class in Italy, which had already begun in 1979, has been devastating.

When accounting for the demise of the workers' movement in Italy, it is important to address not only the effects of repression and fracture, beginning in the late 1970s, but also the inexorable rise, from the 1980s on, of berlusconismo: the absorption of the media by executive power and the general crisis of deconstitutionalisation, par condicio, and legitimo sospetto. Anyone who can bear to watch television in Italy will, between the extravaganzas featuring Rafaella Carrà and Carlo Conti, have encountered the Berlusconi media edifice. It is difficult to describe the effectiveness of berlusconismo in the modulation of collective emotions and sentiment, and the ineffectiveness of a politics based in 'speaking truth to power' or building another possible world in countering this particular articulation of power. Radical political forces in Italy sideline what Italian feminists have called la politica del simbolico at their own peril, underestimating the importance of affect and the imagination in political life and failing to fully analyse the mutual implication of those twin towers of modern political rationality: linguistic representation and political representation. ${ }^{11}$ There is a need to contextualise these fallbacks and inadequacies, to examine the limitations of the operaista legacy with regard to berlusconismo, and to turn this analysis back on a consideration of operaista and postoperaista thought in the global context.

This is a tricky enterprise since radical Italian thought has so much to say about the very global dynamics in which it inserts itself. Like their associates elsewhere, Italian thinkers understand the current era of globalisation as a phase in the history of capitalism. Where they introduce an important and, to my mind, productive difference is in the argument that the history of capital has always involved an attempt to control labour mobility. This is a strain of thought that runs through the work of Ferruccio Gambino, Yann Moulier Boutang and Sandro Mezzadra. ${ }^{12}$ In its widest implication, it contests the codification of the labour relation under capitalism to the terrain of the superstructure and demonstrates how this relation was historically constituted only as one of the forms of subordinate labour which capital has employed in the attempt to attend to its central imperative and challenge: namely, to immobilise the body of the proletarian, to tie it to the labour relation, to prevent its flight. As I attempted to show in 'Né qui, né altrove', the dialogue I published with Sandro Mezzadra a couple of years back, this argument provides a powerful schema for understanding the contemporary migrant detention camp - an argument that not only accounts for but also moves beyond the paradoxes of sovereignty outlined by Agamben. ${ }^{13}$ Combined with the insights of Paolo Virno concerning Marx's understanding of labour power as a form of potentiality (potenza) and the advent of post- 
Fordist capitalism as a kind of permanent de Martinian 'cultural apocalypse' that strips labour back to the precarious capacities that emerge with the anthropogenesis of the human animal, it also has powerful implications for the debates surrounding biopolitics. ${ }^{14}$ But what I want to emphasise are the implications of such an understanding of capitalism for what I am calling, following Dipesh Chakrabarty, the 'provincialisation' of radical Italian thought.15

It is important to acknowledge that this line of investigation is not mine alone but draws upon the experiences of a younger generation of Italian thinkers with whom I have worked and collaborated. These thinkers have inherited the theoretical and political lessons of operaismo but have, at the same time, given them a postcolonial twist, drawing particularly on the 'subaltern studies' writings. ${ }^{16}$ It is no accident that the current Italian interest in postcolonial studies evolves in the postoperaista context, especially as this younger generation of scholars has sought to understand the transformation of Italy from an emigrant to an immigrant country (and the complex economic and cultural shifts associated with this change). Indeed, much of the theoretical investigation of these thinkers has been grounded in the direct experience of activism with labour migrants in Italy (and the European Union more generally). The Genoa protests of 2001, for instance, opened with a self-initiated march by migrants and, as an upshot, prompted the authoring of an open letter by the editors of the journal DeriveApprodi to the social movements of Africa, Asia and Latin America. This letter called for 'the Italian movement to open itself to global dynamics' and recognised the precedents for local struggles in countries like Korea, South Africa, Israel/Palestine, Indonesia and Mexico. ${ }^{17}$ Importantly, the approach to migration pursued by this group of thinkers does not paper over issues of labour and mobility (as has often been the case in the rights-based protests surrounding detention centres in Australia). And it is this element of their thought, explicitly derived from the operaista tradition, which squares with my emphasis on labour as a category that mediates difference.

If, as the passage I quoted earlier from Lotringer and Marazzi suggests, operaista thought proffers the commonality of labour as a means of negotiating contextual specificities, is it legitimate to anchor such thought to Italy and complain, as does Parry of Hardt and Negri's Empire, that its transference to the global context betrays a lack of regard for heterogeneous cultural and economic circumstances? Or does this constitute a dangerous misreading of Hardt and Negri, one that mistakes what they call the common (composed of a multiplicity of singularities and heterogeneities) for the universal? These are the questions we must answer if we are to understand the productivity of the operaista tradition outside of Italy, if we are to track and analyse its global reception, and find translations that can make it politically effective in contexts remote from its initial sites of emergence. 
Let me approach this task by returning to Marx, since, I believe, an inquiry into the fortunes of radical Italian thought as it travels across diverse cultural and geographical circumstances must begin with a consideration of the peculiar qualities of its central category of analysis-that is, Marx's notion of abstract labour. For Marx, abstract labour is the secret of the expression of value, a secret that could only be revealed with the historical constitution of modern capitalism - that is, only in a society where the commodity form had become the universal form of the product of labour and where the dominant social relation was the relation between humans as the producers of commodities. To organise life under the sign of capital is to act as if labour can be abstracted from the concrete social contexts in which it is performed and which make all labour-including the labour of abstraction-perceptibly concrete. In this way, abstract labour provides the hermeneutic grid through which capital allows us to read the world. It is not simply a matter, as Gayatri Spivak points out in 'Scattered Speculations on the Question of Value', that the notion of abstract labour cannot represent labour as extant in the particular and thus makes various qualities of labour (third world labour, women's labour, child domestic labour, and so on) supplements to value as we usually conceive it.18 Rather, it is a more insistent logic that maintains that abstract labour encounters historical difference as something at once inescapable and unassimilable, something that may exist in proximate relation to the institutional logic of the capitalist domination but nonetheless does not belong to its life process.

Chakrabarty gives the example of a worker who enters a factory. ${ }^{19} \mathrm{He} / \mathrm{she}$ represents a historical separation between the capacity to labour and the necessary tools of production (which belong to the capitalist), and thus embodies the universal history of capital. But he/she also carries with him/her ways of being in the world that are other to his/her existence as the bearer of labour power: bodily habits, unselfconscious practices, or cultural tendencies that cannot be automatically aligned with capital's logic. And this raises the possibility that, even in the very abstract and abstracting space of the factory, ways of being human will be enacted (Chakrabarty gives the example of Bengali workers who interrupt their labour to worship machines) in ways that do not lend themselves to the reproduction of capital.

Such a reading of Marx does not obviate the need for an engagement with the universal logic of capital but, at the same time, understands labour as a site where the workings of capital and the politics of human belonging disrupt each other's narratives. No historical form of capital, however global in its reach, can be universal. In its historically available forms, capital is always contextual and multidimensional; it operates along intraregional, transnational, or even subnational lines. There will always remain a need to study these dynamics and paths of flow. But, as Chakrabarty claims, it is also necessary to recognise that the universalism of capital 
functions as a sort of place holder: its 'place is always usurped by a historical particular seeking to present itself as a universal'.20 Without this universalism-which, for Marx, enables the immanent critique of capital-there could only be partial critiques of capital in its various historical manifestations. So universalism and difference must be held in relation, with the latter perpetually crisscrossing and usurping the place of the former.

This story is quite different to that found in the 'Symptoms of Passage' chapter of Hardt and Negri's Empire, where the postcolonial politics of difference (here represented by the work of Homi Bhabha) is signal of the passage to a globally networked capitalism that functions through the production and modulation of differences and hybridities. Certainly, there is a need to acknowledge that difference and hybridisation have emerged as a kind of global style, promoted by marketeers, fashion designers, architects and restaurateurs alike. There can be no question that Hardt and Negri hit their target here. But this does not mean that affective narratives of human belonging, which recognise the porosity of different lifeworlds, can be necessarily equilibrated through a third term such as abstract labour. The translation has to move in both directions. Up through a loving reconstruction of specific cultural and historical circumstances, however diffuse their geographies may be, toward the universal logic of capital. But also down from the global plane on which capital must be opposed to pre-analytic and lived experiences of difference that cannot be abstracted to general categories.

One way of tracing this difference, which I believe allows us to maintain the analytical force of operaista approaches to globalisation while submitting them to translations that are sensitive to the cultural specificities of place, is to return to one of the ur-texts of autonomist Marxist debate: the 'Fragment of Machines' from Marx's Grundrisse. ${ }^{21}$ I don't want to approach this text in the manner of Biblical exegesis. Suffice it to say that whether the 'Fragment' is understood to affirm an 'end of work' hypothesis (as in, say, André Gorz or Jeremy Rifkin) or to announce emergence of the social individual as the foundation of production and wealth (as in the Negri of Marx beyond Marx), it traces the enmeshment of technical and social relations within a general machinic formation. ${ }^{22}$ No longer simply a question of the individual worker's subordination to the rhythms of the industrial machine, the logic of the factory is extended to society as a whole where capital seeks to control the entire ensemble of sciences, languages, knowledges, activities and skills that Marx designates with the terms general intellect or social brain.

In the history of operaismo two main stories are told about this real subsumption. For Tronti, there is a kind of emptying out of subjectivity that accompanies this movement away from (or, more precisely, opening out of) the factory-an anxiety that arises with the emergence of what he called la rude razza pagana or the subject's passage on to the general social plane 
where consumption, integration and anomie begin to dominate. Whereas, for Negri, there is a kind of fullness of subjectivity, a ripening or maturation of the subject he initially called the mass worker (which anticipated the figure of the social worker he would derive in the 1980s and the concurrent recuperation of Spinozan ontology that would eventually inform the project of Empire). Both of these positions or (better) tendencies (I admit they are caricatures that need further argument) seem mystifying to me. Perhaps because both buy into an implicit progressivism that takes the revolutionary subject as already formed rather than as a kind of propulsive force in the process of formation. There is a tendency to view the highest stage of capitalism (the moment of real subsumption) as the point at which revolutionary potential is most pregnant. And this seems to ignore the temporal complexity of the relation between potential and act-the fact that, as Paolo Virno argues in Il ricordo del presente, this relation is not only temporalised but temporalising or, more precisely, consists not simply in chronological passage or temporal order but rather in the junction between the order of that which passes and the passage of that which orders. ${ }^{23}$

To bring the argument back to the terms of Marx's analysis, we can say, with Chakrabarty, that it is dangerous to focus the debate around the transition from the formal to the real subsumption. Not only does this enforce a normative model of development, which the postcolonial rhetoric of temporality has worked so hard to discredit, but also it obscures the possibility of examining the plural histories that capital encounters, incorporates, and overwhelms in its process of globalisation. For Chakrabarty, formal and real subsumption hybridise and exist side by side, not simply as a moment of what Jameson (after Bloch) calls the synchronicity of the nonsynchronous, but in a more radical temporal movement that brings the 'now' and 'not-now' into contact with each other. ${ }^{24}$ This is a logic that cannot be reduced to the binary cause/effect, which levels the heterogeneity of potential and act to the homogeneity of two acts, two 'nows' separated by the ticking of the chronos. Rather it is the movement by which capital historicises metahistory, a metahistory that must, as Virno insists, be understood both as the biological invariant of life itself and the abstracted capacity to labour. ${ }^{25}$ Historical difference is not external to capital but rather constitutive of it. Or, in other words, capital's self-realisation is interrupted by singularities that are not subordinated to its logic and these supply the grounds for claiming difference.

A number of implications flow from this:

1. There is the need to extend Marx's analysis of the general intellect not simply in terms of political organisation but also in relation to cultural conditions: anthropological, affective, psychic, everyday and communicative relations through which the auto- 
organisation of a society that can liberate itself from capital might be imagined. But these cultural conditions will clearly diverge and interpenetrate, requiring different approaches and vocabularies depending on location and degree of complexity. Thus there is a need for cultural translation not as a substitute for political relation but as the very condition of its possibility and effectiveness.

2. These differences must be returned to the body and the bios. There is a need to recognise this at a level that goes beyond the Hardt and Negri footnote that states: 'the most profound and solid problematic complex that has yet been elaborated for the critique of biopolitics is found in feminist theory'. ${ }^{26}$ The feminist politics of relation, which refuses and works below the politics of representation/equality, cannot be added as a mere footnote to the corpus of radical Italian thought. At a time when a global 'war against terrorism' is waged by postconstitutional powers that deploy media affect to modulate collective emotions and sentiments, we cannot forget the words of Carla Lonzi in her deliciously titled 1970 Sputiamo su Hegel (Let's Spit on Hegel): 'The world of equality is the world of legalised oppression and one-dimensionality. In the world of difference, terrorism discards its weapons and oppression yields to the variety and multiplicity of life.'27

3. A politics that interrupts the universal logic of capital with the pre-analytic experience of difference cannot retreat to the consolations of nationalism. The most novel aspect of the movement that first expressed itself in Seattle and later exploded in Genoa is its opening to the global dimension. As such, it offers an opportunity to establish channels for the political communication of struggles, experiences and knowledge at the planetary level. This is an opportunity that can be realised through pragmatic engagements in the politics of cultural translation. And such engagements must involve the recognition that the global movement, whatever current difficulties it encounters in the redefinition of its political horizon, carries in its material constitution hopes and struggles that arise from outside the advanced capitalist world.

Perhaps, finally, it is best not to speak of an Italian effect. Certainly, radical Italian thought has demonstrated a remarkable productivity outside its initial context of formation and provides, in all its heterogeneity, one of the most potent theoretical-political apparatuses for the interpretation of current global tendencies. But can this productivity be contained within the binary logic of cause and effect? Or does it dangle without a prime motivator, like a mess of potentialities that swarm beneath the actual, chemically reacting with the here and now? The attempt to understand the transportability of Italian political thought vis-à-vis its own encounter 
with Marx's concept of abstract labour yields an understanding of cultural translation that emphasises not the relation between two given and separable actualities but a dynamic and open relation of potentiality, an encounter with difference that interrupts the universal logic of capital without relinquishing the critical force that an encounter with such universalism can bring. This relation of potentiality cannot be reduced to the temporality of cause and effect, the chain of action and reaction that, for Leibniz, vouchsafed the existence of a transcendental deity. Rather, in its openness, it must always operate in two directions, continually feeding back to question and alter its founding presuppositions. Indeed, it is by provincialising radical Italian thought, by subjecting it to such translations, that its political limits and internal stumbling blocks might be acknowledged and overcome. And, for this reason, the encounter with radical Italian thought outside Italy must remain central to its attempts to face a new panorama, to devise modes of thinking and practice that can oppose and subsist beneath the present condition of global war.

Brett Neilson is Senior Lecturer in the School of Humanities at the University of Western Sydney, where he is also a member of the Centre for Cultural Research. He is author of Free Trade in the Bermuda Triangle ... and Other Tales of Counterglobalization, University of Minnesota Press, Minneapolis, 2004. 
${ }^{9}$ Guido Borio, Francesca Pozzi, and Gigi Roggero, 'Intervista a Christian Marazzi, 5 Luglio 2000', on the CD accompanying Guido Borio, Francesca Pozzi, and Gigi Roggero (eds), Futuro anteriore. Dai Quaderni Rossi ai movimenti globali: richezze e limite dell' operaismo Italiano, DeriveApprodi, Rome, 2001.

${ }^{10}$ Sylvere Lotringer and Christian Marazzi, 'The Return of Politics', in Sylvere Lotringer and Christian Marazzi (eds), Autonomia: Postpolitical Politics, Semiotext(e), New York, 1980, pp. 8-21.

11 On the mutual implication of political and linguistic representation see Luisa Muraro, Maglia o unicinetto: racconto linguistico-politico sull'inimicizia fra metfora e metonomia, manifestolibri, Rome, 1998. See also the introduction by Ida Dominijanni to this same volume, 'La parola del contatto,' especially pp. 19-20.

12 Ferruccio Gambino, Migranti nella tempesta: avvistamenti per l'inizio del nuovo millennio, Ombre Corte, Verona, 2003; Yann Moulier Boutang, De l'esclavage au salariat: économie historique di salariat birdé, Puf, Paris, 1998; and Sandro Mezzadra, Diritto di fuga: migrazioni, cittadinanza, globalizzazione, Ombre Corte, Verona, 2001.

13 Sandro Mezzadra and Brett Neilson, 'Né qui, né Altrove: Migration, Detention, Desertion. A Dialogue', borderlands ejournal, vol. 2, no. 1, 2003,

<http://www.borderlandsejournal.adelaide.edu.au/vol2no1_2003/mezzadra_neilson.html>.

${ }^{14}$ Paolo Virno, Quando il verbo si fa carne: linguaggio e natura umana, Bollati Boringhieri, Torino, 2003.

15 Dipesh Chakrabarty, Provincializing Europe: Postcolonial Thought and Historical Difference, Princeton University Press, Princeton, 2000.

16 For an exemplary collection of essays in this regard see DeriveApprodi magazine, no. 23. This issue, entitled Movimenti postcoloniali, combines translations of English-language works with pieces by younger Italian thinkers such as Sandro Mezzadra, Federico Rahola, Marcello Tari, Miguel Mellino and Paolo Godani. A revised version of the introductory essay will soon be available in English: Sandro Mezzadra and Federico Rahola, 'The Postcolonial Condition: A Few Notes on the Quality of Historical Time in the Global Present', Postcolonial Text, forthcoming, $<$ http://www.pkp.ubc.ca/pocol/>.

17 'Open Letter and Call for Papers from the Italian Magazine DeriveApprodi', <http://mail.sarai.net/pipermail/reader-list/2002-December/001986.html>.

18 Gayatri Chakravorty Spivak, 'Scattered Speculations on the Question of Value', in In Other Worlds: Essays in Cultural Politics, Methuen, London, 1987, pp. 154-75.

19 Chakrabarty, p. 66.

20 Chakrabarty, p. 70.

21 Karl Marx, Grundrisse, trans. Martin Nicolaus, Penguin, London, 1973.

22 André Gorz, Farewell to the Working Class: An Essay on Post-Industrial Socialism, trans. Michale Sonenscher, Pluto, London, 1982; Jeremy Rifkin, The End of Work: The Decline of the Global Labour Force and the Dawn of the Post-Market Era, Putnam, New York, 1995; and Antonio Negri, Marx beyond Marx: Lessons on the Grundrisse, trans. Harry Cleaver, Michael Ryan, and Maurizio Viano, Bergin and Garvey, South Hadley, Mass., 1984.

23 Paolo Virno, Il ricordo del presente: saggio sul tempo storico, Bollati Boringhieri, Torino, 1999.

24 Frederic Jameson, Postmodernism, or, the Cultural Logic of Late Capitalism, Duke University Press, Durham, 1989.

25 Paolo Virno, 'Diagrammi Storico-Naturali: Movimento New Global e Invariante Biologico', Forme di Vita, vol. 1, 2004, pp. 104-116.

26 Hardt and Negri, Empire, pp. 422-3.

27 Carla Lonzi, 'Let's Spit on Hegel', in Paola Bono and Sandra Kemp (eds), Italian Feminist Thought, Blackwell, Oxford, 1991. 